\title{
A Potential Solution to Unintelligible English Accent: an Orthoepic Study of the Effectiveness of Stress Placement Intervention for Chinese English Speakers
}

\author{
Liwen Liu \\ Department of Foreign Languages and Literatures, Chung Hua University, No. 707, Section 2, Wufu Road, \\ Hsinchu City, 300, Taiwan, Republic of China
}

*Corresponding Author: Liwen Liu, Department of Foreign Languages and Literatures, Chung Hua University, No. 707, Section 2, Wufu Road, Hsinchu City, 300, Taiwan, Republic of China

\begin{abstract}
Chinese students often make quite a few stress placement mistakes when they say multi-syllable English vocabulary due to the interference of the traditional pronunciation patterns exhibited in their first language. Moreover, the shortage of stress-placing knowledge in the target language further corrupts the accent in their word-level utterance. This research seeks a solution to this problem with an "counting of word endings". A method that predicts the primary stress in a polysyllabic word. Chinese learners of English who practice this supra segmental feature to remove the bad accent which interferences the intelligibility of their verbal communication to their English interlocutors. Students are first given a pretest of a group of polysyllabic words to expose how their natural English rhythm is, thus to see how wrong they are in their stress patterns and stressing habits. The result of the pretest exhibited that a clear absent of English stress knowledge in students' pronunciations. Students then received a 30-hour teaching intervention on how to predict s word's primary stress by a set of algorithm of word suffixes. A posttest of a different group of long English words with same suffixes is given to the students again after the stress pattern tutoring sessions are finished. The improvement in scores in the posttest indicates the rate of students' progress in their stress placement and intelligibility in their pronunciations to native English speakers and thus proves the effectiveness of this stress prediction drill intervention introduced.
\end{abstract}

Keywords: Algorithm in word endings, Intelligibility, Primary word stress placement, Polysyllabic word, Supra segmental feature

\section{INTRODUCTION}

Although English has continued to grow as a major language spoken internationally, many non-native speakers have found learning to say English vocabulary correctly difficult because of proper word stress placement. This study was conducted to demonstrate the effectiveness of word stress rules, created by Canadian linguist George Waldo (1968), in improving the pronunciation of English by Chinese college students. Given the problems associated with the pronunciation of English by nonnative American speakers. The purposes of this research were two-fold.

The first purpose was to provide Chinese college students with a simple approach to learning English word stress in order to help them learn to say Englishwords more authentically. Waldo formalized a system of stress rules for English vocabulary words by analyzing their morphological structures. His intent was to show non-native English learners, who possessed almost no knowledge of English phonology, which vowel(s) should have the primary stress when they encountered new words. Prator and Robinett (1972) asserted that familiarity with word stress rules "will give purpose and direction to students' [oral] reading, and perhaps enable them to progress from the point at which they can avoid a given 'error' by conscious effort to the point where they make the correct sound automatically when they are thinking only of the meaning of the words" (p.xvii). They suggested that if the rules are skillfully carried out, they "can be of great value as a means of progressing gradually from the conscious to the unconscious control of a feature of pronunciation, as a way of adding one more analyzed element to the synthesis of normal speech" (Prator \& Robinett, 1972, p.xviii). 
The second purpose was to examine the effectiveness of Waldo's system of stress prediction rules to justify their adoption by English language instructors. Waldo's rules were examined using repeatedmeasure tests and a stress rule intervention procedure with a class of twenty Chinese college English majors to establish the results of word stress prediction rules on the participants' pronunciation.

\section{REVIEW OF RELATED LITERATURE}

\subsection{Significance of English Word Stress}

Over the last half century, the English language has risen to the pinnacle of the world's linguistic hierarchy, giving native English speakers an advantage over others in international affairs, business and trade. Non-native speakers who wish to compete on a level playing field must acquire native-like accuracy in English pronunciation, for which accurate word stress is an essential prerequisite. According to Rubin (2005), word stress is key to comprehensibility in the English language. He says that non-native speakers can get by with fairly pronounced accents as long as they conform to English norms for intonation. Accurate placement of word stress enhances the comprehensibility of non-native speaker's speech because accented English pronunciation resulting from stressing the wrong vowel often makes a non-native speaker sound strange and unintelligent, and therefore to be distrusted or dismissed by native speaker (Pathare, 2005). For instance, if a Chinese-speaking person wants to communicate effectively with an English speaker, the first thing he needs to do is to master English word stress patterns: Word stress is important in pronunciation and good pronunciation contributes to effective communication.

It is often said that "to correctly stress an English word appears to be one of the major difficulties in the pronunciation of English" (Wijk, 1966, p.124). Word stress in English is not a luxury that one can add or delete at will. It is an integral part of the English language. English speakers need word stress to communicate rapidly and accurately, even in difficult conditions ("Rules of word stress in English," n.d.). If a person does not hear a word clearly, he can still understand the word because of the position of the stress. For example, even entry-level English students can easily and quickly differentiate between the words photograph and photographer by hearing only the first two syllables of these words. Pathare (2005) mentions that word stress is crucial in pronunciation because it affects syllables and the segments that constitute syllables, as seen in the stress alternation in English between certain nouns and verbs e.g., CONduct vs. conDUCT. Stressing a word differently can change the meaning altogether.

As O'Connor (1973) asserts, “[I]n English, stress is a significant factor because it is an essential part of word-shape; words easily become unrecognizable if the stress is wrongly placed" (p. 194).

The English language has free word stress (O'Connor, 1973, p. 233) which means the "stress can be in anywhere in a word; there is no single position where the stress of a word can be expected to fall in English" (Quirk et al., 1985, p. 1590). For example, counting from left to right, it may fall on the: 1st vowel: SYnonym 2nd vowel: caNAry 3rd vowel: evaNESCE 4th vowel: responsiBIlity 5th vowel: osteopoROsis 6th vowel: industrialiZAtion In some cases, stress is flexible, and shifting the primary stress onto the secondary stress syllable matters very little to the listener's comprehension of the word. Take the word ambidexter for example: According to Waldo (1968, p. 124) pronouncing it as either AMbidexter or ambiDEXter will not strike the listener as wrong, because switching the primary and secondary stresses between AMand DEX produces similar rhythmical patterns. In general, however, Quirk et al., (1985) emphasize that "[A]lthough as speakers, people have a good deal of freedom in assigning stresses in utterances longer than a word, the placing of the stress within English words is save for relatively minor exceptions - so rigorously invariant that it is often difficult for the hearer to understand a word where the accentuation is deviant (p. 1590)."

Consider the following two examples: 1. imPORTant vs. IMportant 2. ENergy vs eNERgy Moving the primary stress from the second syllable to the first as in example 1, or from the first to the second as in example 2, could be enough to make the word incomprehensible or misunderstood (Quirk et al., 1985). Such interactions have important implications not only for speech production but also for comprehension (Odlin, 1989). Research studies have also shown that interchanging the primary and secondary stress or misplacing the stress "result[s] in comprehension failure more readily than wrong sound" (Bowen, Madsen, \& Hilferty, 1985, p.134). 
Indeed, stress patterns play a crucial role in listeners' recognition of words. When non-native speakers fail to use a stress pattern that is customary to the target language, the pronunciation of vowels and consonants may also vary from the target pattern, which can result in total misperception by listeners. Errors in stress are the leading causes of unintelligibility in second language speakers' pronunciation of English. For instance, "diVIsionswas sometimes pronounced DIvisions and was consequently misperceived by English listeners as Regions"(Odlin, 1989, p. 117). When someone stresses the wrong syllable, miscommunication can occur. "If a speaker of English stresses the wrong syllable, it may be quite impossible for anyone listening to understand what the speaker is trying to say" (Prator \& Robinett, 1972, 107p.18). "Even if the speaker can be understood, mistakes with word stress can make the listener feel irritated, or perhaps even amused, and can prevent good communication from taking place" (Bowen, 2004).

According to Simich-Dudgeon (1989), "[O]ne of the most distinctive elements in an English word is stress-a salient characteristic that is not indicated in the English writing system." People cannot tell where the stress should fall in a word by looking at its spelling. Therefore, if there are grammar rules to govern English word order and sentence structure, then one must ask whether a similar set of rules can exist to predict word stress. "The science of phonology may be considered the grammar of pronunciation and knowledge of phonology will help non-native speakers to pronounce no less, and no more, than a knowledge of grammar will teach students to speak and write" (Prator \& Robinett, 1972, p. 2).

\subsection{Necessity of English Word Stress}

Even though Prator and Robinett (1972, p. 19) assert that "unfortunately, there are no infallible rules for determining which syllable of a word should be stressed," Quirk et al., (1985, p.1591) suggest that "although it is widely known that the stress pattern of each polysyllabic word has to be learned separately, we shall presently see that some valuable generalizations can be made." Cruttenden (1997) emphasizes the importance of word stress rules as well: "Any description of English word stress rules inevitably involves a large number of exceptions. However, a general rule with exceptions is more economical than listing every word as an exception" (p. 15). Waldo (1968) encourages all those who suffer from the complexity of word stress patterns that "there are rules that cover about $97 \%$ of the words" (p. 1). Though it is not possible to lay down any completely satisfactory rules for the stressing of English words, it should be emphasized that "there are vast numbers of words which do not offer any difficulty at all in this respect" (Wijk, 1966, p. 124). "Statistically, there are very few words on an average page for which the placement of stress cannot be determined through rules. Around ninetyfive percent of the running words on an average page are from the three thousand commonest words in the language, and few of those are irregular" (Wijk, 1966, p. 124).

English Word stress prediction rules Modified from Waldo's Model (1968) Given the lack of practicality of stress prediction models based on syllabification, George S. Waldo's (1968) model seems much more promising for Chinese English learners because it mainly avoids syllabification. Waldo's research and rules rely on recognizing word endings and counting vowels from the end of the word, techniques that should be amenable to learning by EFL students. According to Waldo (1968), it is best to classify English words by the phonetic nature of their endings when trying to determine where to apply the primary stress. At the top level Waldo's rules, words are divided into ones that end with one or more consonants $(\mathrm{C})$ and ones that end with one or more vowels $(\mathrm{V})$. These groups are further subdivided into $(-\mathrm{CC}),(-\mathrm{CVC})$ and $(-\mathrm{VVC})$ for consonant endings, and $(-\mathrm{CCe}),(-\mathrm{CVCe}),(-$ $\mathrm{VVCe}),(-\mathrm{VV}),(-\mathrm{V})$ and $(-\mathrm{Cy})$ for vowel endings; the codes represent patterns of vowels $(\mathrm{V})$ and consonants $(\mathrm{C})$, with the lower-case letters (e and $\mathrm{y}$ ) standing for themselves.

These nine types of word endings largely determine the location of their main stress with a few exceptions. However, two other factors must also be considered. First, the part of speech of words can affect stress placement. For example, sometimes two-syllable nouns and adjectives are stressed on the first syllable and two-syllable verbs and adverbs are stressed on the second syllable. Second, the number of the words can affect stress as well. For example, "sometimes two-syllable words are stressed according to their parts of speech, while words with three or more syllables are stressed according to the two-consonant rule" (Waldo, 1968, p.31). The diagram in Figure 1 illustrates the relationships between these factors. 


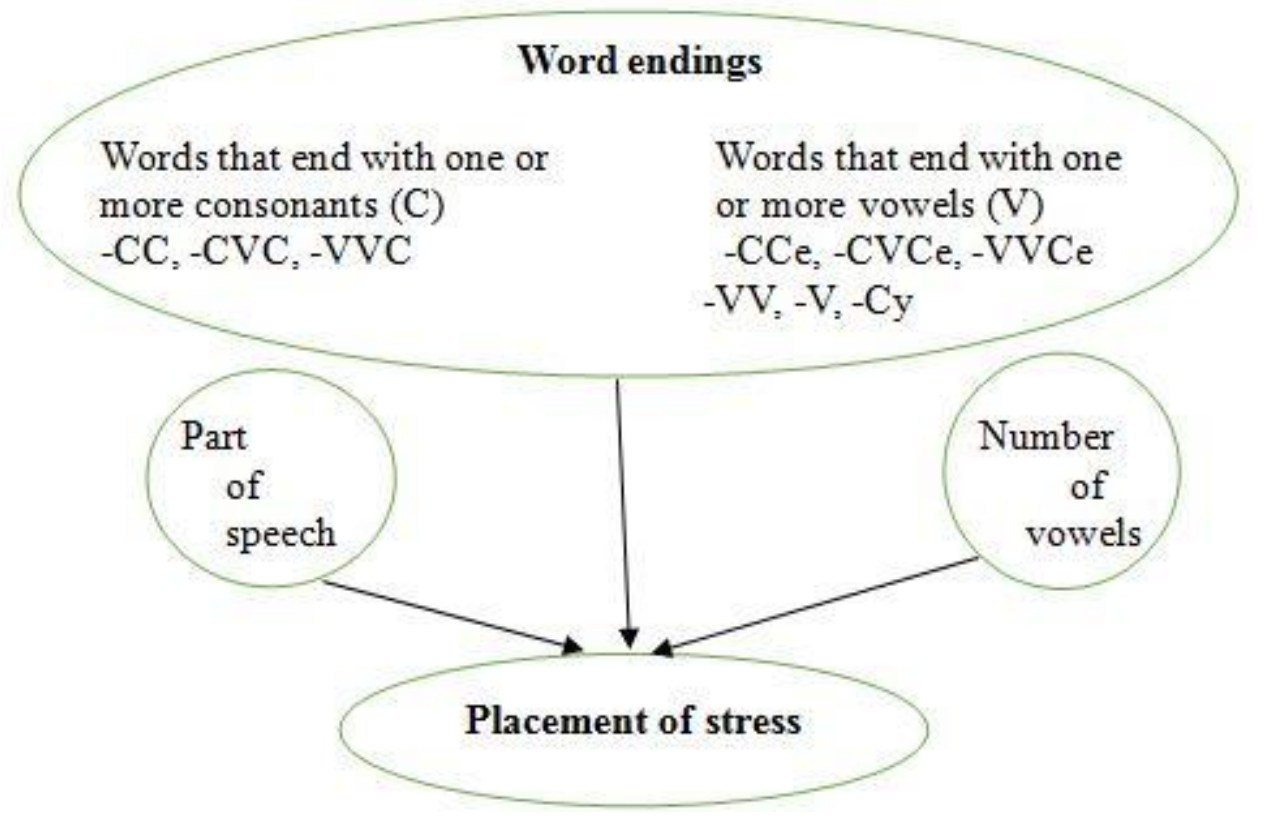

Figure1. Factors Affecting Stress Placement in Waldo's Model

Although Waldo's rules below deal with letters rather than syllables, many of the same fundamental principles apply. It is well known that "the influence of suffixes on the stressing of words is particularly important," "most sets of rules for the stressing of English words involve counting the number of syllables working backwards from the end of the word rather than from the beginning" (Cruttenden, 1997, pp.16-17). Thus, when a rule states "-ish: first vowel before the ending", the vowel to be stressed is the last one that occurs before the ending "-ish" e.g. the "u" in "publish". There is also a very common rule that is referenced throughout the rule set, called the "two-consonant rule". The rule states that if the word ending is preceded by two or more consecutive consonants, the stress may fall on the vowel right before these consonants. If the ending is preceded by only one consonant or one vowel, then the stress may fall on the second vowel before the ending, if the word is long enough to have two vowels before the ending. If the word has only two vowels i.e. two-syllable words, then the stress will fall on the second vowel from the end, that is, the first syllable of the word (Waldo, 1968, p. 36). For example, if a word ends in -ment: With two consonants before the ending: aMENDment, and abSURDment. With only one consonant before the ending: enterTAINment, and SEGment With only one vowel before the ending: DOCument, and SETtlement. Waldo's rules are presented both by category and in alphabetical order for readers' fast and easy access. Students who are interested in learning the principles of the nine types of word endings are encouraged to look for them in the category list. Those who only need to know the stress placement of a particular word will find it more convenient to consult the alphabetical list in the same way they look for a word in a regular dictionary except that they need to scan the word backwards. Finally, English is a complex language, and the rules cannot cover all possible cases. If a word fits a rule pattern but the rule cannot be applied to it e.g., it puts the stress on the third vowel before the ending, but such an application yields an unacceptable result, it is an exception and must be looked up in a regular dictionary. Naturally, there are exceptions. "In a comparatively small group of words the stress falls on the prefix not only when they are used as nouns, but also when they are used as verbs. Examples: combat, comfort, comment, compliment, envy, exercise, exile, implement, interest, issue, offer, profit, promise, purpose, purchase, rescue, supplement" (Wijk, 1966, p.131).

\section{Materials AND Methods}

\subsection{Research Questions and Hypotheses}

\section{Research Questions}

For the purpose of this study, the following research questions were developed:

1. Is there a difference between the scores of correct word stress placements by both the control group and the experiment group after the experiment group is tutored in stress placement rules, as evaluated based on Webster's Dictionary of dictionary words? 
A Potential Solution to Unintelligible English Accent: an Orthoepic Study of the Effectiveness of Stress Placement Intervention for Chinese English Speakers

2. Is there a difference between the scores in the intelligibility of both groups assigned by native English speakers after the experiment group is tutored in stress placement rules?

3. Is there a correlation between the objective stress placement evaluation results and the subjective intelligibility scores for experiment group after the intervention?

\section{Research Hypotheses}

This study investigated the following corresponding research hypotheses:

$H 1_{0}$. There is no statistically significant difference between the scores of correct word stress placements by both the control group and the experiment group after the experiment group is tutored in stress placement rules, as evaluated based on Webster's Dictionary of dictionary words.

$H 2_{0}$. There is no statistically significant difference between the scores in the intelligibility of both groups assigned by native English speakers after the experiment group is tutored in stress placement rules.

$H 3_{0}$. There is no positive statistical correlation between the objective stress placement evaluation results and the subjective intelligibility scores for experiment group after the intervention.

\section{RESULTS AND DISCUSSION}

This study presented information about the practicability of the stress prediction model rules for nonnative English learners, such as Chinese college students. The findings are essential for college EFL teachers and administrators to understand students' challenges in vocabulary pronunciation. The following findings were drawn from the descriptive statistical results generated through the research hypotheses.

The first research question thought to determine whether there was a statistically significant difference in the scores of correct word stress placements on the 20 dictionary pronounced by 20 Chinese students in the experimental group before and after being tutored in stress placement rules. The results of paired-samples $t$-tests indicated statistically significant differences, from 50.75 (out of 100) to 70.75 (out of 100) points in the scores of correct word stress placements between the pre- and postintervention test scores. With 19 degree of freedom, the critical value of $t$ was 2.093 for a two-tailed test at a .05 significance level. With the obtained $t$ value being 8.71 , which fell well outside the acceptance range, the null hypothesis 1 , which claimed no statistically significant difference in the scores of correct word stress placements between two tests, was rejected. The statistical data suggested students improved significantly in the scores of correct word stress placements after the stress rule intervention. See Table 1 below.

\section{Table 1 for Research question 1}

Comparison of the word stress placement scores of 20 dictionary words before and after the stress rule intervention for the experiment group. $(N=20)$

Mean (Std. Deviation)
Dimension
Pretest Posttest

\begin{tabular}{lllllll}
\hline Score & $50.75(15.06)$ & $70.75(14.16)$ & 19 & 8.71 & .000 & 2.75
\end{tabular}

Research question 2sought to determine whether there was a statistically significant difference between the intelligibility scores on the 20 dictionary words pronounced by the 20 Chinese students in the experimental group before and after being tutored in stress placement rules. The results of pairedsamples $t$-tests suggested significant increases, from 50.90 (out of 100) to 61.25 (out of 100) points in the students' intelligibility scores between the pre- and post-intervention tests. With 19 degree of freedom, the critical value of $t$ was 2.093 for a two-tailed test at a .05 significance level. With the obtained $t$ value being 5.93, which fell well outside the acceptance range, the null hypothesis 2 , which claimed no statistically significant difference in the intelligibility scores between two tests, was rejected. The statistical differences in data between the two tests suggested students did improve their intelligibility after the stress rule intervention. See Table 2 below. 
A Potential Solution to Unintelligible English Accent: an Orthoepic Study of the Effectiveness of Stress Placement Intervention for Chinese English Speakers

\section{Table 2 for Research question 2}

Comparison of the pronunciation scores of 20 dictionary words before and after the stress rule intervention for the experiment group. $(N=20)$

Mean (Std. Deviation)
Dimension
Pretest

\begin{tabular}{lllllll}
\hline Score & $50.90(9.44)$ & $61.25(12.35)$ & 19 & 5.93 & .000 & 1.87
\end{tabular}

Research question 3 sought to determine whether the correct word stress placement in English vocabulary words positively correlated with the intelligibility of the English vocabulary words. Statistical results suggested a strong positive Pearson's correlation coefficient $(r(38)=.64, p=<.001)$ between the scores of correct word stress placement and the score of whole word intelligibility on the 20 dictionary words. With ther value being .64, null hypothesis 3 was rejected. The statistical data suggested that the more accurately the word stress was placed, the more intelligible the words sounded. See Table 3 below.

\section{Table 3 for Research question 3}

The correlation result between the scores of correct word stress placement and the scores of word pronunciation on 20 dictionary words for the experiment $\operatorname{group}(N=40)$

\begin{tabular}{l}
\hline Stress Placement score - \\
Pronunciation score $\quad .70 * *$ \\
\hline$* p<.05 * * p<.01 * * * p<.001$
\end{tabular}

\section{CONCLUSIONS}

Correctly stressing syllables in the pronunciation of English words has played an essential part in oral communication because misplaced syllable emphasis often results in failure of a listener to recognize spoken words. Because of the considerable dissimilarity in the articulatory nature of Chinese and English vocabulary and the serious lack of authentic oral modeling in the classroom, Chinese students who are taught English as a foreign language (EFL) have received little phonological education. Stress placement of word syllables has long been recognized as an important aspect in the instruction of pronunciation within Chinese English curricula; however, concrete improvements in teaching methods have proven elusive. Consequently, Chinese students have become incapable of correctly stressing English words orally, which sound hesitant, inarticulate, and sometimes completely unintelligible to a native English speaker.

The purpose of this study was to demonstrate the effectiveness of word stress prediction rules created by Canadian linguist George Waldo in improving the pronunciation of English words by Chinese college students. These rules were used to predict syllable emphasis through a word's orthography, i.e. letter sequences, thus requiring minimum phonetic knowledge in understanding how to place correctly emphatic stress on the syllables of unfamiliar English words. This study attempted to validate the rules of Waldo's model by evaluating their effectiveness on twenty Chinese college English majors. Repeated-measures of paired pre- and post-intervention tests, with a month long stress rule intervention, were implemented in order to compare Chinese students' performance on oral vocabulary reading before and after being tutored in stress placement rules. The statistical findings of the paired-samples t-tests suggested that there were significant improvements in both the students' word stress placement using Webster's Dictionary as an evaluation standard and the students' word intelligibility according to native English evaluators' comprehension after the intervention.

A strong positive Pearson correlation coefficient between correct word stress placement and word intelligibility supported the thesis of this study: correct stress placement increases authenticity in pronunciation, which thereby enhances non-native speakers' oral intelligibility by native speakers. This study produced statistical evidence to demonstrate the potential of stress prediction rules in helping EFL learners better their English vocabulary pronunciation. By correctly accenting syllables, non-native speakers of English are able to eliminate unwanted foreign accents, reduce the likelihood 
of miscommunication with English speakers, and improve the overall intelligibility of their spoken English.

\section{REFERENCES}

[1] Waldo, G.S. (1968). Stress the right syllable: The accentuation of English words. Edmonton, Alberta. pp.1, pp.36

[2] Prator, Jr. C.H., \& Robinett, B.W. (1972). Manual of American English pronunciation (3 ${ }^{\text {rd }}$ ed.). New York, NY: Holt, Rinehart \& Winston, Inc. pp. xviii, pp.2, pp.18 pp.19

[3] Rubin, D. L. (2005, April 7). What we have here is a failure to communicate. The Chronicle of Higher Education. Retrieved January 29, 2006, from http://chronicle.com/colloquy/2005/04/english/

[4] Pathare, E. (2005). Word Stress. Retrieved January 29, 2006, from http://www. teachingenglish.org.uk/ think/pron/word_stress.html

[5] Wijk, A. (1966). Rules of pronunciation for the English language. London, England: Oxford University Press. pp.124, pp.131

[6] O’Connor, J. D. (1973). Phonetics. Maryland: Pelican books Ltd.pp. 194, pp. 233.

[7] Quirk, R., Greenbaum, S., Leech, G., \& Svartvik, J. (1985). A comprehensive grammar of the English language. Reading, MA: Addison Wesley Publishing Co. pp.1590 pp.1591.

[8] Odlin, T. (1989). Language transfer: Cross-linguistic influence in language learning (p.115). Cambridge, England: Cambridge University Press. pp.134, pp.117

[9] Simich-Dudgeon, C. (1989). English literacy development: approaches and strategies that work with limited English proficient children and adults. NCBE FOCUS: Occassional papers in Bilingual education (Number 12, Summer 1989). Retrieved April 4, 2006, from http://www.ncela.gwu.edu/pubs/ classics/focus/12eld.htm

[10] Cruttenden, A. (1997). Intonation (2nd ed.). Cambridge, England: Cambridege University Press. pp.15 pp. 17

\section{APPENDIX}

Include:

1. A sampleof pre-test scoring sheet

2.A sample of post-testscoring sheet

3. A sample of native speaker scoring sheet

4. A sample of Stress prediction rules

1. Pre-test scoring sheet:

Name: Score:

1. employee

50

2. pinnacle

50

3. gymnastics

50

4. arthritis

50

5. mutineer

50

6. allograph

50

7. integrity

50

8. imbecile

50

9. antenna

50

10. hypnosis

50

11. encyclopedia

50

12. sanctimony

50

13. esoteric

50

14. indelible

50

15. fluctuate

50 


$\begin{array}{lcc}\text { 16. vainglory } & 5 & 0 \\ \text { 17. graffiti } & 5 & 0 \\ \text { 18. rebellion } & 5 & 0 \\ \text { 19. meridian } & 5 & 0 \\ \text { 20. cartulary } & 5 & 0\end{array}$

2. Post-test scoring sheet

Name: Score:

1. volunteer 50

2. epistolary 50

3. alimony 50

4. kleptomania 50

5. obstacle 50

6. holograph 50

7. juvenile 50

8. photography 50

9. gingivitis 50

10. allegory 50

11. oblivion 50

12. safari 50

13. aromatic 50

14. enigma 50

15. amphibian 50

16. guarantee 50

17. comprehensible 50

18. conjunctivitis 50

19. statistics 50

20. collegiate 50

3. Native Speaker scoring sheet

Please circle what you feel about the pronunciation of the following words:

Score:

1. Incomprehensible

2. Incomprehensible

3. Incomprehensible

4. Incomprehensible

5. Incomprehensible

6. Incomprehensible

7. Incomprehensible

8. Incomprehensible

9. Incomprehensible

10. Incomprehensible

11. Incomprehensible

2

Guessable

Guessable

Guessable

Guessable

Guessable

Guessable

Guessable

Guessable

Guessable

Guessable

Guessable

Guessable

Guessable

Guessable

Guessable

Guessable

Guessable
3

4

5

Native-like

Native-like

Native-like

Native-like

Native-like

Native-like

Native-like

Native-like

Native-like

Native-like

Native-like

Native-like

Native-like

Native-like

Native-like

Native-like

Native-like 


$\begin{array}{llllll}\text { 18. } & \text { Incomprehensible } & \text { Guessable } & \text { Fair } & \text { Decent } & \text { Native-like } \\ \text { 19. Incomprehensible } & \text { Guessable } & \text { Fair } & \text { Decent } & \text { Native-like } \\ \text { 20. Incomprehensible } & \text { Guessable } & \text { Fair } & \text { Decent } & \text { Native-like }\end{array}$

4. Sample of word stress prediction rules

1. 以-ee 做字尾的單字:重音位置在字尾-ee 上例如:

a.GREE (v.)同意; 贊成

$\mathrm{ab} \cdot \operatorname{sen} \cdot \mathrm{TEE}$ (n.)缺席者;不在場者

$\mathrm{ad} \cdot \mathrm{dress} \cdot \mathrm{EE}$ (n.)收信人;收件人

ap·poin·TEE (n.)被任命者，【律】被指定的財產受人

ban·SHEE (n.)預告死亡的女妖精

con·sign·EE (n.)承銷人;受託者;收件人

de·bauch·EE (n.)浪蕩子

de·GREE (n.)度,度數,程度;等級,學位;學銜,地位;身分;階層

dun·ga·REE (n.)粗棉布的一種，用粗棉布做的褲子、工作服等

em·ploy·EE (n.)受雇者,雇工,雇員,從業員工

en·dors·EE (n.)原收款人自己背書以讓渡的對象

fi·an·CEE (n.)【法】未婚妻

fil·· $\cdot G R E E(n$.$) 似花邊的金銀絲細工飾品(vt.)用金銀絲細工飾品裝飾$

fric·as·SEE (vt.)把...烹製成原汁肉塊 (n.)油燘原汁肉塊

gran·DEE (n.) (西班牙或葡萄牙的最高爵位)大公，顯貴,要人 guar·an·TEE

(v.) 保證；擔保 (n.) 保證 ; 擔保

in·tern·EE (n.)(戰爭期間)被拘留者

ju·bi·LEE (n.) (尤指二十五週年、五十週年等的)紀念(或慶典)，歡慶

kill·DEE(n.)一種小水鳥[北美產]

li·bel·EE (n.)(被)控告者

li cens'EE (n.)獲許可的人;領到執照的人

mat $\cdot \mathrm{i} \cdot \mathrm{NEE}(\mathrm{n}$.$) 午後的演出;日戲;日場$

me·LEE (n.)【法】互毆;混戰;混亂

mort·gag·EE (n.)【律】受抵押人

nom $\cdot \mathrm{i} \cdot \mathrm{NEE}(\mathrm{n}$. .) 被提名人 
ped·i·GREE (n.)家譜,系譜, 家世,血統,出身

prom·is·EE (n.)【律】受約人

ref·er·EE (n.)(籃球、足球、拳擊等的)裁判員(vt.) (vi.)仲裁, 停

ref·u·GEE ( n.)難民;流亡者

ru·PEE (n.)盧比(印度、斯里蘭卡等貨幣單位)

$\operatorname{soi} \cdot R E E$ (n.)【法】晚會;社交聚會

tou·PEE (n.)假髮

trans·fer·EE ( n.)【律】受讓人,承買人, 被調任者

2. 以-ia 做字尾的單字: 重音在字尾-ia 前第一個音節上

a.PHA.sia (n.)【醫】失語症

ady·NA·mia (n.)【醫】衰弱

$\mathrm{al} \cdot \mathrm{LU} \cdot \mathrm{vi} \cdot \mathrm{a}$ (n.) (alluvium 的複數) 沖積層;沖積土

al $\cdot o \cdot P E \cdot c i a(n$.$) 秃頭症$

am·MO·nia (n.)【化】氨,阿摩尼亞;氨水

$\mathrm{am} \cdot \mathrm{NE} \cdot \mathrm{sia}(\mathrm{n}$.$) 【醫】記憶缺失; 健忘(症)$

am·PHIB·ia (n.) 【動】兩棲類

an·OS·mia (n.)【醫】嗅覺喪失症

an· o REX·ia (n.) (病理學) 厭食症

as·PHYX·i·a (n.) 【醫】窒息;悶死

bac·TE·ri·a (n.) (bacterium 的複數) 細菌

be.GO·nia (n.)【植】秋海棠屬植物

bib·lio·MA·nia (n.) 藏書癖; 珍本書收藏狂

BRON·chia (n.) 支氣管

$\mathrm{bu} \cdot \mathrm{LI} \cdot \mathrm{mi} \cdot \mathrm{a}(\mathrm{n}$.$) (病理學)暴食症$

ca.MEL·lia (n.) 山茶花

$\mathrm{CIL} \cdot \mathrm{i} \cdot \mathrm{a}(\mathrm{n}).(\mathrm{pl}$.)【植】纖毛，【動】纖毛，睫毛

claus·tro·PHO·bia (n.)【醫】幽閉恐怖症

CRA·ni·a (n.) (cranium 的複數) 頭蓋骨 
cri·TE·ri·a (n.) (criterion 的複數)(判斷、批評的)標準,準則

DAHL·ia (n.) 【植】大麗花

de.MEN·tia (n.) 癡呆

dys·PHA·gia (n.)【醫】嚥下困難

dys·PEP·sia (n.) 消化不良

en $\cdot$ cy·clo $\cdot$ PE·di·a (n.) (=encyclopaedia)百科全書;大全

eu·tha·NA·sia (n.) 安樂死

fan·TA·sia (n.) 幻想曲，集成曲

FAS·cia (n.) 帶;飾帶; 【醫】繃帶，招牌，(汽車的)儀錶板

gas.tro·DYN.i·a (n.) 胃痛

GLO·ri·a (n.)【拉】榮耀頌詩;榮光,一種絲毛混織品

he $\cdot \mathrm{mo} \cdot \mathrm{PHIL} \cdot \mathrm{i} \cdot \mathrm{a}(\mathrm{n}$.$) 【醫】血友病$

HER·ni·a (n.)【醫】疝氣

hy·dro·PHO·bia (n.) 狂犬病

hy·po·CHON·dri·a (n.) 憂鬱症

hys·TER·i·a (n.) 歇斯底里

in·SIG·ni·a (n.) (常複數)表示階級、團體成員身分等用的佩章、衣飾等

in·SOM·nia (n.) 【醫】失眠症

3.以-Cy 做字尾的單字(但非-acy， - ny或-ry做字尾的單字): 重音在字尾-Cy

前第二個音節上例如:

NOR·mal·cy (n.) 常態; 正常

COM·e·dy (n.) 喜劇,喜劇性,喜劇成分,喜劇性事件

CUS·to·dy (n.) 照管;保管;監護,拘留;監禁

HYM·no·dy (n.) 唱讚美詩;作讚美詩;讚美詩研究

JEOP·ar·dy (n.) 危險,風險,危難, 【律】(被告處於被判罪或受處罰的)危險境地

MAL $\cdot a \cdot d y(n$.$) 病,疾病, (社會的)弊病,腐敗,歪風$

MEL·o·dy (n.) 悅耳的聲音;美妙的音樂,歌曲;可詠唱的詩,【音】旋律;主調,音樂性

PAR·o·dy (n.) 諷刺性模仿詩文;詼諧的改編詩文,拙劣的模仿;春事 
PROS·o·dy (n.) 作詩法;詩體論;韻律學

PSALM·o·dy (n.) 聖歌吟唱,讚美詩集

REM·e·dy (n.) 治療;治療法;藥物, 補救(法);糾正(法),賠償,補償

RHAP·so·dy (n.) 吟誦史詩;狂詩,狂文;【音】狂想曲

SUB·si·dy (n.) 津貼, 補貼; 補助金, (一國為換取另一國軍事援助而給的)財政援助

THREN·o·dy (n.) 輓歌,悲哀;哀悼

TRAG·e·dy (n.) 悲劇體裁, (一齣)悲劇,悲劇性事件;慘案;災難,悲劇因素

4. 以-ile 做字尾的單字:重音位置在該字第一音節上例如:

AG·ile (adj.)輕快的,敏捷的;機敏的,靈敏的

CAM·o mile (n.) 甘菊;春黃菊屬植物

CROC·o·dile (n.)䱾魚,鰏魚皮革,成縱列慢步行進的人

DOC·ile (adj.)馴服的;易駕御的容易教的;可教的

FAC·ile (adj.)易做到的;易使用的;熟練的;流暢的

FAC·sim·i·le (n.)摹寫,傳真 $(v t)$ 摹寫 ; 與...一模一樣

FE·brile (adj.)易裂的;可裂的

FER·tile (adj)多產的,繁殖力強的,肥沃的;豐饒的,豐產的,能生育的;豐富的

FIS·sile (adj.)熱性的;發熱的,發熱所引起的

FRAG·ile (adj.)易碎的;脆的;易損壞的,脆弱的;虛弱的,纖細的,精細的

FU·tile (adj.)無益的,無效的,不重要的,微不足道的; (人)愚蚌的,沒有出息的

GEN·tile (n.)非猶太人;異教徒 (adj.)非猶太人的;異教徒的

HOS·tile (adj.) 敵人的,敵方的;懷敵意的;不友善的

IM·be·cile (n.)低能者,優子(adj)低能的;極愚春的

IN.fan·tile (n.)幼稚的;嬰兒的

JU·ve·nile (adj.)少年的,適合少年的;少年特有的,孩子氣的,未成熟的

MIS·sile (n.)飛彈; 導彈,投射物; 投射武器(adj) 可發射的,可投擲的

MO·bile (adj.) 可動的,多變的,能快速移動的,機動的(n.)【美】汽車活動物體;

PRO-file (n.)側面,側影,輪廓; 外觀,形象,人物簡介 $(v t)$ 給...畫側面圖像,描出...輪廓, PRO·jec·tile (n.)拋射體;發射體,射彈(如子彈、砲彈等) 
REC·on·cile (vt.)使和解,使和好，調停,調解, 調和;使一致

SE·nile (adj.)老邁的;高齡所致的;老態龍鍾的

SER·vile (adj.)奴隸的;卑賤的,低下的;奴顏卑膝的,屈從的

$S I M \cdot i \cdot l e(n$.$) 直喻; 明喻$

STER·ile (adj.)不生育的;不結果實的，貧瘉的;消過毒的,無菌的

SUB·tile (adj.)(=subtle)微妙的,難以捉摸的,纎細的;隱約的,細心的,敏銳的

TAC·tile (adj.) (有)觸覺的,能觸知的; 有形的

TEX·tile (n.)紡織品;紡織原料(adj)紡織的

VER·sa·tile (adj.)多才多藝的,活動的;可四面轉動的,易變的;反覆無常的

VIR.ile (adj.) 男人的;有生死力的;強壯的;剛健的

VOL·a tile(adj)易發揮的,爆炸性的; 易發作的,活潑的; 輕快的,飛逝的; 短暫的

\section{AUTHOR's BIOGRAPTHY}

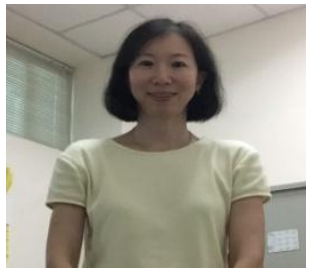

Liwen Liu, is an associate professor who has been teaching English as a foreign language in Chung Hua University in Taiwan, Republic of China. She has focused her research on phonetic study, especially in phonotactics and in suprasegmentalfeatures such as syllable stress. She is currently working on a book that helps Chinese English learners to eliminate and self-correct their accents when pronouncing English vocabulary.

Citation: Liwen Liu. "A Potential Solution to Unintelligible English Accent: an Orthoepic Study of the Effectiveness of Stress Placement Intervention for Chinese English Speakers" International Journal on Studies in English Language and Literature (IJSELL), vol 9, no.4, 2021, pp. 14-26. doi: https://doi.org/10.20431/23473134.0904002.

Copyright: (C) 2021 Authors. This is an open-access article distributed under the terms of the Creative Commons Attribution License, which permits unrestricted use, distribution, and reproduction in any medium, provided the original author and source are credited. 